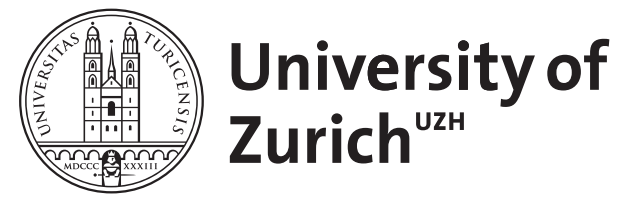

Zurich Open Repository and Archive

University of Zurich

University Library

Strickhofstrasse 39

CH-8057 Zurich

www.zora.uzh.ch

Year: 2017

How could religion become a category? : accounting for classical and fuzzy logic in the conceptualization of religion

Amsler, Monika

Posted at the Zurich Open Repository and Archive, University of Zurich

ZORA URL: https://doi.org/10.5167/uzh-161774

Journal Article

Published Version

Originally published at:

Amsler, Monika (2017). How could religion become a category? : accounting for classical and fuzzy logic in the conceptualization of religion. ASDIWAL, (12):38-51. 


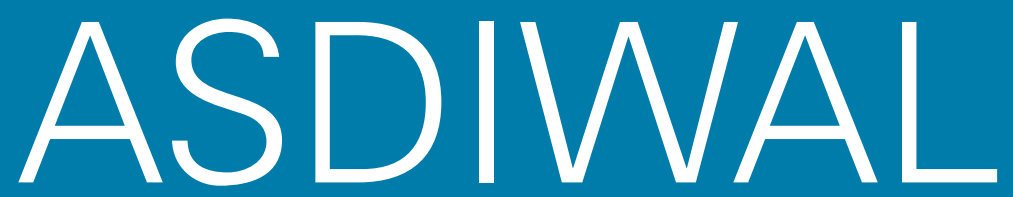

Revue genevoise d'anthropologie et d'histoire des religions

N $\circ 12$

Genève 


\section{ASDIWAL}

Revue genevoise d'anthropologie

et d'histoire des religions

Numéro $12-2017$

\section{DIRECTION \\ SECRÉTAIRE DE RÉDACTION}

COMITÉ SCIENTIFIQUE

COMITÉ DE RÉDACTION ET MISE EN PAGE

WEBMASTER

REVUE PUBLIÉE AVEC LE SOUTIEN DE
CONCEPTION GRAPHIQUE

Daniel Barbu, Francesco Massa, Philippe Matthey, Nicolas Meylan

Mélanie Lozat

Nicole Belayche, Corinne Bonnet, Philippe Borgeaud, Renaud Gagné, Vincent Goossaert, Cristiano Grottanelli †, Eduard Iricinschi, Dominique Jaillard, Bruce Lincoln, Alain Monnier t, Maria Patera, Gabriella Pironti, Francesca Prescendi Morresi, Guy G. Stroumsa, Christoph Uehlinger, YOURI VOLOKHINE

Daniel Barbu, Chloé Berthet, Violaine Duc, Mélanie Lozat, Francesco Massa, Philippe Matthey, Sara Petrella, Juliette Salzmann, Nicolas Meylan, Aurélie Schneider, Aurore Schwab, Marie Voide, Sonia Voinea

\section{Cédric Siegenthaler}

Deniz Ates

Société Suisse pour la Science des Religions

Unité d'histoire des religions, Université de Genève

Académie Suisse des Sciences Humaines et Sociales

Loterie Romande

\section{ASDIWAL}

CORRESPONDANCE

c/o Unité d'histoire des religions Université de Genève

2, rue de Candolle

$\mathrm{CH}-1211$ Genève 4

www.asdiwal.ch info@asdiwal.ch

ISSN 16624653

ISBN 978-2-9700939-4-7

Format: $24 \times 17 \mathrm{~cm}$

Pagination: 226 pages Imprimerie SEPEC à Péronnas (France)

\section{Revue genevoise d'anthropologie et d'histoire des religions} est une publication scientifique avec comité de lecture. Tous les textes proposés seront soumis à l'évaluation du Comité scientifique. Ils doivent répondre aux normes éditoriales disponibles à l'adresse www.asdiwal.ch. Les propositions peuvent être envoyées sous format électronique à l'adresse info@asdiwal.ch. La revue peut accueillir, dans ses numéros thématiques, des actes de colloque. La revue ASDIWAL, émanation de la Société genevoise d'histoire des religions, paraît chaque année depuis 2006. Son siège est établi à l'Université de Genève, Faculté des lettres, Unité d'histoire des religions. 


\section{Sommaire}

\section{Entretiens}

Bernard Faure 7

Russel McCutcheon 23

\section{Études}

MONIKa AMSLER

How Could Religion Become A Category? Accounting for Classical and Fuzzy Logic in the Conceptualization of Religion 37

Moshe BLIdstein Swearing by the Book: Oaths and the Rise of Scripture in the Roman Empire

Corinne Bonnet Le vin et "les vrais rois ». Approche comparée du lien entre ivresse et transmission du pouvoir

MAGALI BossI Les mandéens selon les voyageurs français du xVII siècle 93

Pierre VesperinI La culture antique était-elle une "culture de la transmission»? Façons grecques et façons romaines de faire passer les savoirs

AmÉLIE WARD L'argile absorbe notre chagrin. La revivification du rituel indigène Kopi Mourning Cap à Melbourne

\section{Notules d'histoire des religions}

YourI VolokHINe Septième série ( $\$ 30$ à 33 ) 153

\section{Recherche}

Sara Petrella

Dieux en métamorphose: Regards croisés sur la Mythologie, c'est-à-dire Explication des fables (Lyon, 1612)

Aurore SchWAB

L'émergence de la norme internationale sur le "crime d'honneur" dans la perspective de l'histoire des religions

\section{Comptes rendus}

Anton Alvar Nuño, Cadenas invisibles. Los usos de la magia entre los esclavos en el Imperio romano, Besançon, Presses Universitaires de Franche-Comté, 2017 (Thomas Galoppin); Corinne Bonnet, Vinciane Pirenne-Delforge, Gabriella Pironti éds, Dieux des Grecs, dieux des Romains. Panthéons en dialogue à travers I'histoire et I'historiographie, Bruxelles - Rome, Institut Historique Belge de Rome, 2016 (Fritz Graf) ; Bernard Chapais, Aux origines de la société humaine. Parenté et évolution, Paris, Seuil, 2017 (Christophe Lemardelé); Guillaume Ducoeur, Claire Muckensturm-Poulle dir., La transmigration des âmes en Grèce et en Inde anciennes, Besançon, Presses Universitaires de Franche-Comté, 2016 (Philippe Bornet); VINCENT Goossaert, Bureaucratie et salut. Devenir un dieu en Chine, Genève, Labor et Fides, 2016 (Chloé Berthet); Michael Konaris, The Greek Gods in Modern Scholarship: Interpretation and Belief in Nineteenth and Early Twentieth Century Germany and Britain, Oxford, Oxford University Press, 2016 (Nicolas Meylan); Adam Knobler, Mythology and Diplomacy in the Age of Exploration, Leiden - Boston, Brill, 2017 (Philippe Borgeaud); Valeria PIANo, Il papiro di Derveni. Tra religione e filosofia, Firenze, Leo S. Olschki, 2016 (Anaïs Marchiando); Verity Platt, Facing the Gods. Epiphany and Representation in Graeco-Roman Art, Literature and Religion, Cambridge, Cambridge University Press, $2016^{2}$ et Georgia Petridou, Divine Epiphany in Greek Literature and Culture, Oxford, Oxford University Press, 2015 (Anne-Françoise Jaccottet); AnNECaroline Rendu Loisel, Les chants du monde. Le paysage sonore de l'ancienne Mésopotamie. Avec un appendice d'Ariane Thomas, Toulouse, Presses Universitaires du Midi, 2016 (Doralice Fabiano); ANDrEA Rota, La religion à l'école. Négociations autour de la présence publique des communautés religieuses, Zurich - Genève, Seismo, 2017 (Camille Gonzales); Nickolas P. Roubekas, An Ancient Theory of Religion. Euhemerism from Antiquity to the Present, New York - Londres, Routledge, 2016 (Philippe Borgeaud); Guy G. Stroumsa, Religions d'Abraham. Histoires croisées, Genève, Labor et Fides, 2016 (Christophe Lemardelé); Sharon Weisser, Naly Thaler éd., Strategies of Polemics in Greek and Roman Philosophy, Leiden - Boston, Brill, 2016 (Andrei Timotin). 
Mots-clés:

concept de religion;

formation de catégories;

logique classique;

logique floue,

paradigme moderne,

magie

Keywords:

concept of Religion;

category formation;

classical logic

fuzzy logic;

modern paradigm;

magic
How Could Religion
Become A Category?

Accounting for Classical

and Fuzzy Logic in

the Conceptualization

of Religion

Monika Amsler

University of Zurich

\section{Résumé:}

Les sciences religieuses font face à des défis continus concernant la nature comparative du terme "religion ". Jusqu'ici, aucune définition satisfaisante n'a été proposée. De plus, depuis un demi-siècle, on ne cesse de soutenir que le terme est intrinsèquement chrétien (protestant) et moderne. Des études récentes affirment en outre que le terme «religion» en tant que catégorie devrait être abandonné. Cet article analyse les modalités permettant de transformer la "religion" en une catégorie et quel rôle la catégorisation a joué dans la recherche et l'épistémologie modernes. L'article montre que l'incapacité de l'histoire des religions à fixer son objet résulte de l'absence d'alternative à la logique classique. Bien qu'il existe de plus en plus de preuves que la logique classique ait atteint ses limites en tant qu'outil épistémologique, les logiques postmodernes n'en diffèrent pas substantiellement. Cet article est un appel à la contribution active des spécialistes de la science de religion dans la quête pan-académique d'une véritable alternative à la logique classique. Dans les disciplines traitant de la religion une nouvelle logique devrait mener à un concept de "transcendance sans contraire" (Latour). Pour y parvenir une première étape pourrait consister à abandonner l'idée de la religion en tant que catégorie pour travailler avec des concepts inscrits dans le temps et dans l'espace.

\section{Abstract:}

The Study of Religion faces continuous challenges regarding the comparative nature of the term "religion ». So far, no definition has been offered that could account for its deficiencies. Moreover, for half a century now it was continuously argued that the term is inherently Christian (Protestant) and modern. Recent studies further claim that the use of "religion" as an analytical category should be abandoned. The present article asks how, in fact, "religion" could become a category and what role categorization came to play in the modern academy and in modern epistemology. It is demonstrated that the constant running in circles in the Study of Religion with regard to its own subject results from the lack of a true alternative to classical logic. Even though there is a growing body of evidence suggesting that classical logic has reached its limits as an epistemological auxiliary, postmodern logics do not differ substantially. This paper is a call for an active contribution of scholars of religion in the pan-academic quest for a true alternative to classical logic. In the Study of Religion a new logic should enable the concept of "transcendence without contrary" (Latour). To achieve this, a first step might be to drop the idea that religion is a category and, instead, work with time- and space-bound concepts. 


\title{
How Could Religion Become A Category? Accounting for Classical and Fuzzy Logic in the Conceptualization of Religion
}

\author{
Monika Amsler \\ University of Zurich
}

\section{Of Protestant and Modern Dichotomies and Categories}

The term religion seems to remain bulky, even though the major pitfalls have been under discussion for more than 50 years now 1 . It still causes more problems than it helps solve ${ }^{2}$. Not wide enough to include everything it should to be of comparative utility, the term is at the same time too broad to be defined. It seems to smack of Protestant Christianity and yet, the general notion of religion still differs considerably from Protestant Christianity ${ }^{3}$. A number of definitions have been proposed and rejected and we seem to walk in circles, asking ourselves repeatedly "Haven't We Been There Before? " ${ }^{4}$, without finding an escape.

A recent attempt at "Reconstructing Religion from the Bottom Up" was taken by Wouter J. Hanegraaff. In this article, Hanegraaff shows that the inherent Protestantism of religion is founded in its dichotomy to magic. This dichotomy is the reason why religion can never become the comparative term it was intended to $b^{5}$. Hanegraaff points out that in comparative studies,

Cf. for example the substantial critique of the article by Rosalie WAX, Murray WAX, "The Notion of Magic ", Current Anthropology 4/5 (1963), pp. 495-518.

2 Cf. for example most recently Brent Nongbri, Before Religion: A History of a Modern Concept, New Haven, Yale University Press, 2013; Russell T. Mccutcheon, "The Category "Religion" in Recent Publications: Twenty Years After ", Numen 62.1 (2015), pp. 119-141; Carlin A. Barton, Daniel Boyarin, Imagine No Religion. How Modern Abstractions Hide Ancient Realities, New York, Fordham University Press, 2016; Daniel Dubuisson, Religion and Magic in the Western Culture, Leiden - Boston, Brill, 2016; Wouter J. HanegraffF, "Magic», in Glenn A. Magee ed., The Cambridge Handbook of Western Mysticism and Esotericism, New York, Cambridge University Press, 2016, pp. 393-404.

3 Cf. for the former argument for example Wouter J. HanegraAfF, "Reconstructing "Religion" from the Bottom Up", Numen 63.5-6 (2016), pp. 577-606; for the latter, Benson Saler's discussion of Daniel Dubuisson, The Western Construction of Religion: Myths, Knowledge and Ideology, Baltimore - London, John Hopkins University Press, 2003 (L'Occident et la religion: mythes, science et idéologie, Bruxelles, Complexe, 1998), in Benson SaLER, "Concept of Religion", in Robert A. Segal, Kocku von Stuckrad eds., Vocabulary for the Study of Religion, Leiden, Brill, 2014 (accessed online 02-01-2018).

4 See, for example, the article with this very title by AARon Hughes, "Haven't We Been Here Before? Rehabilitating "Religion" in Light of Dubuisson's Critique", in Steven Engler, Dean Miller eds., Review Symposium: Daniel Dubuissson, The Western Construction of Religion, Religion 36.3 (2006), pp. 127-131.

5 Cf. HanegraAfF, "Reconstructing Religion", art. cit., pp. 588-589, sketching a " crisis of comparison ". 
religion is used as a tertium comparationis, i.e. the assumption by which something is compared to something else. By defining religion by way of contrasting it with magic, this dichotomy becomes part of the tertium comparationis as well. Inevitably, the comparanda will be compared with regard to such a dichotomy ${ }^{6}$. As a result of such comparisons, only concepts that posit a similar dichotomy will be considered as «religion». Thus, religion should not be defined against a dichotomous "other", by which Hanegraaff exclusively refers to magic. Based on this, he proposes a working definition, which should help free the tertium from such an inherent Protestantism as the distinction between religion and magic. According to this definition (inspired by Clifford Geertz), religion is a "symbolic system that influences human action by providing possibilities for ritually maintaining contact between the everyday world and a more general meta-empirical framework of meaning ${ }^{7}$ (my emphasis).

The emphasis shows that this definition cannot do without a dichotomous "other " either. It implements a dichotomy between everyday and meta-empirical frameworks. This dichotomy is indeed not a Protestant one but a rephrasing of dichotomies central to the modern paradigm, namely nature, society, and the transcendent ${ }^{8}$. Thus, while a tertium comparationis that maintains the dichotomy between religion and magic may rightly be judged as influenced by Protestant theology, the definition proposed by Hanegraaff as an alternative tertium is distinctly modern. It is modern, because it is based on a paradigm of separate spheres, in this case an everyday world, a "between » and a meta-empirical framework (i.e. transcendence). If this definition of religion is used as a tertium and applied on a culture that does not share the paradigm of separate spheres, then there is no religion. This tertium defines a religion not based on a Protestant Christian prototype, but on a modern one ${ }^{9}$.

\section{Modern Reason}

After the uncovering of crypto-Protestantism in the Study of Religion and magic, as done by Hanegraaff and others in recent years, it might be time to address "crypto-modern reasoning " as well. However, in its basic assumptions the latter is not as distinct from the former as commonly assumed.

The use of the term "modern" requires qualification, since it has been used in different contexts and with various nuances. Thus, when Bruno Latour's book We Have Never Been Modern was published in its English translation in 1993, the publisher adorned the front page with the picture of a Viking helmet, which to him apparently symbolized a non-modern condition.

6 On comparison as an analytical tool, cf. Ralph Weber, "On Comparing Ancient Chinese and Greek Ethics: The tertium comparationis as a Tool of Analysis and Evaluation", in RICHARD A. H. KIng ed., The Good Life and Conceptions of Life in Early China and Graeco-Roman Antiquity, Berlin - Boston, De Gruyter, 2015, pp. 29-56. HANEgraAfF, "Reconstructing Religion", art. cit., pp. 598-599, is referring to a previous and less elaborate contribution by RALPH WEBER on this subject, "Comparative Philosophy and the Tertium: Comparing What with What, and in What Respect?", Dao 13 (2014), pp. 151-171.

7 HanegraAfF, "Reconstructing Religion", art. cit., p. 601.

8 Cf. Bruno Latour, We Have Never Been Modern, Cambridge, MA, Harvard University Press, 1993 (Nous n'avons jamais été modernes: essai d'anthropologie symétrique, Paris, La Découverte, 1991), pp. 29-35.

9 In the following the term modern is used not in a qualifying manner but as reference to an epoch. The unspecific nature of such epochs should not be of concern. Indeed, it seems that in the endeavor for precision in the so-called inexact sciences, the paradox of precision and certainty has been neglected. The paradox states: The more precise the less certain and vice-versa; cf. Constantin V. Negoita, "The Poetic License of the Fuzzy Paradigm ", in VLADIMIR Dimitrov, Victor Korotkich eds., Fuzzy Logic, Berlin - Heidelberg, Springer, 2002, pp. 94-98, here pp. 94-95. 


\section{Monika Amsler}

This provocation is enhanced by the fact that the English translation does not render the subtitle of the French original: Essays of a symmetrical Anthropology. Judging from this cover, one might think that the book was either written to describe non-modern conditions or to accuse modern men of not being modern enough. Yet, the exact opposite is true. Latour shows that the implementation of modern ideas is not possible in reality and that it would be better to stop forcing it. Modernity, in Latour's sense, is a way of generating knowledge by means of classification of previously isolated structures, phenomena, signs, and things, which lead to a proliferation of non-classifiable hybrids. Classifications, on the other hand, lead to dichotomies ${ }^{10}$. The most fundamental modern dichotomy is the one between the human and the non-human. It is followed by other, more and more detailed dichotomies, the next general ones being the dichotomies between nature, society, and the transcendent. Many of the less fundamental dichotomies have been negotiated in recent postmodern discussions, for example the cultural dichotomy between " us and them », i.e. the modern and the non-modern world. In general, the disciplines of the modern academy reflect the principal divisions still quite well.

Three laws (initially by Aristotle) have come to govern modern classification and make-up the framework, the "laws of thought», of modern reason or "classical logic»:

- The law of bivalence: "A proposition is either true or false ";

- The law of non-contradiction: " $A$ is not non- $A$ "; 12

- The law of the excluded middle: "There is no third that is at the same time $A$ and non-A $»^{13}$.

All of these three laws are about making distinctions and about clarifying the dichotomy between $A$ and non-A. Aristotle himself may have had rather tangible cases of application in mind, the modern interpretation of his laws, however, applies them to much more abstract things and signs as well - basically to everything ${ }^{14}$. So much so that modern men gradually came to "require a dualist attitude ${ }^{15}$ in order to be at peace with themselves.

Why, then, should "crypto-modern reasoning" be a problem if this is how classical academic logic works? To follow Hanegraaff's argument again: because it generates a biased tertium comparationis. The modern paradigm rests on distinct premises and is therefore not necessarily compatible with other paradigms. Modern concepts, that is, concepts generated on the basis of modern logic, will only consider comparanda based on a different logic as nonscientific, unreasonable or, according to the law of bivalence, as simply «false ». They may also, and this is what I suspect Hanegraaff's definition does, subtly transfer modern reason onto a different logical framework, thereby positing modern logic as a universal.

10 On dichotomies cf. Latour, op. cit., pp. 11, 97-100.

11 Cf. Jean-Yves Béziau, "Bivalence, Excluded Middle and Non Contradiction », in Libor Behounek ed., The Logica Yearbook 2003, Prague, Academy of Sciences, 2003, pp. 73-84, here p. 74.

12 Joseph E. Brenner, Logic in Reality, Heidelberg, Springer 2008, here p. 2.

13 Ibid.

14 For the position of Aristotelian logic in Western intellectual history, cf. [https://plato.stanford.edu/entries/aristotlelogic/] (accessed 11-9-2017). Kant, for example, "thought that Aristotle had discovered everything there was to know about logic, and the historian of logic Prantl drew the corollary that any logician after Aristotle who said anything new was confused, stupid, or perverse" (ibid).

15 LATOUR, op. cit., p. 102. 
Moreover, "crypto-modern reasoning" keeps the Study of Religion (and no doubt other disciplines as well) trapped in the conflict between modern academic reason and postmodern critique of this very reason. This is a vicious circle, since postmodern argumentation follows these three laws as well. Even non-classical postmodern logics never criticize and revise more than one of the three laws and can therefore be translated back into classical logic ${ }^{16}$. Thus, in its failure to propose a real alternative to classical logic, postmodern deconstruction rather reinforces than criticizes modern assumptions.

In the Study of Religion, modern arguments and postmodern counterarguments have led to the two-sided agreement that religion is, in fact, a category.

\section{The Naturalization of Religion as a Category: Part I}

Religion has already been conceptualized in many ways: as something bigger and more universal than its offshoots, the so-called world-religions; as "natural religion" or phenomenon or otherwise essential; as an evolutionary step in our episteme; as a system of symbols or beliefs and, most recently, as a category. While the first notions on this list have received considerable attention both in their development and deconstruction, the category has been adopted without much ado. Apart from Robert Baird's Category Formation and the History of Religions (1971) there seems to have been no substantial discussion of the matter ${ }^{17}$.

For Baird, however, the transition from phenomenon to category was a major shift in the (historical) Study of Religion, because it signified the transition from the "essential-intuitional method ${ }^{18}$ to a focus on definition ${ }^{19}$. What was adopted in the discipline, however, was not Baird's own (functional) definition but the different types of definitions he described.

However, the various definitions that have been proposed for religion were based on individually chosen prototypes according to expertise. Therefore, no definition was comparative enough to serve for research undertaken with another focus (see also discussion below). The quest for a consensual definition for religion, a basic requirement for a category, was thereupon steadily abandoned 20 .

Via a cluster of modifying adjectives, however, the "category religion" could be retained despite the lack of a definition. The most frequent of these qualifiers is "heuristic ». The idea of a "heuristic category" might be a remote spin-off from Algebra, where categories were

16 Cf. Dov M. GabBay, "Classical vs. Non-Classical Logic (The Universality of Classical Logic)», in Dov M. GabBAY, Chris J. Hogger, John A. Robinson eds., Handbook of Logic in Artificial Intelligence and Logic Programming, Vol. 2: Deduction Methodologies, Oxford, Oxford University Press, 1994, pp. 359-457.

17 Robert D. Baird, Category Formation and the History of Religions, The Hague, Mouton, 1971.

18 Ibid, pp. 2-5.

19 Definitions were generally thought to supply a "criterion for the exclusion of what was literally nonsense "; ISAIAH Berlin, "Logical Translation", in Henry Hardy ed., Concepts and Categories: Philosophical Essays, vol. 2, London, Pimlico, 1978, pp. 56-80, here p. 73. This "nonsense» was feared as a relapse into metaphysics.

20 The proposed definitions involve real, lexical, nominal and stipulative (or functional) as well as working definitions. For a detailed explanation of these types of definitions, cf. BAIRD, op. cit., pp. 4-16; more concisely, see HANEGRAAFF, "Reconstructing", op. cit., p. 584. On definitions for religion in general see Michael Stausberg, Mark Q. Gardiner, "Definition», in Michael Stausberg, Steven Engler éds., The Oxford Handbook of the Study of Religion, Oxford, Oxford University Press, 2016, pp. 9-32. 


\section{Monika Amsler}

introduced for heuristic purposes ${ }^{21}$. However, without any explanation of the heuristics that the scholar intends to apply, the label "only disguises the fact that scholars wish to avoid defining the (supposedly) undefinable and instead resort to pre-theoretical or even everyday language, thereby leaving the task of sense-making to their readers ${ }^{22}$.

Before discussing other types of categories proliferating in the field, it may be worth looking at the very nature of categories first. This will help to answer the question of how religion could become an undefined category.

\section{Philosophy and Implication of Categories}

Category formation has reached the Study of Religion via several disciplines. Baird pointed to "anthropologists, sociologists, physical scientists, and logicians ${ }^{23}$. For the present purposes, the above-mentioned spin-off from a so-called exact science, mathematics, shall be discussed. This will not only provide some basic information concerning the nature of categories but dismantle prejudices concerning the exactness of category theory. Recently, there has been increasing awareness that the evaluation of data is by no means less decision-choice based in higher mathematics than in the Humanities ${ }^{24}$.

Category theory was introduced into Algebra in 1942 by Professors Samuel Eilenberg and Saunders Mac Lane, though only in the margins and as an auxiliary device. They used categories as axiomatic definitions for heuristic purposes. The intellectual context of the theory was structuralism, in which mathematics and humanities interacted "closely and fruitfully ${ }^{25}$. A result of these interactions was structural mathematics. Category theory combined structuralism with the "axiomatic method" as introduced by David Hilbert and adopted by Albert Einstein. This method demands "the sharp separation of the logical form" and the realistic and intuitive contents ${ }^{26}$. This separation is achieved via the postulation of axioms. However, the ridge between the conscious use of a self-posited axiom as an auxiliary in research and the notion that an axiom is a self-evident universal truth is narrow. Indeed, "(a) drawback of Hilbert's axiomatic revolution [...] is the revival of the traditional metaphysical thinking (that Kant calls dogmatic) in the new cloths of formal logical methods. Tarski's world of individuals and classes would be still there even if the empirical science would not exist and would not be possible ${ }^{27}$. Thus, the very idea of the axiomatic method is deeply connected to the search for a dogmatic truth, quite similar to the purpose of dogmatic theology.

21 Jean-Pierre Marouis, "What is Category Theory?", in Giandomenico Sica ed., What is Category Theory?, Monza, Polimetrica S.a.s., 2006, pp. 221-256, here p. 222.

22 Bernd-Christian Otto, "Magic and Religious Individualization. On the Construction and Deconstruction of Analytical Categories in the Study of Religion », Historia Religionum 9 (2017), pp. 29-52, here p. 38.

23 BaIRD, op. cit., p. 1.

24 Cf. Kofi K. Dompere, Fuzziness and Foundations of Exact and Inexact Sciences (Studies in Fuzziness and Soft Computing 290), Berlin - Heidelberg, Springer, 2013, pp. 1-14

25 Andrel Rodin, Axiomatic Method and Category Theory, Cham, Springer, 2014, p. 236 and ibid. for the afterlife of structuralism in North-American mathematics.

26 Albert Einstein, quoted in ibid., p. 245.

27 Ibid., p. 245. Mathematician Alfred Tarski (1901-1983) «is widely considered as one of the greatest logicians of the twentieth century (often regarded as second only to Gödel), and thus as one of the greatest logicians of all time"; cf. Stanford Encyclopedia of Philosophy, s.v. «Alfred Tarski» [https://plato.stanford.edu/entries/tarski] (accessed 01-22-18). 
Members of a category are equal and share one or more features. Since categories are axioms they allow "to see the universal components of a family of structures of a given kind $»^{28}$. Thus, category theory is a "dream come true" for structuralists in that structures that share a certain characteristic can be gathered and posited as self-evident universals ${ }^{29}$.

Further, categories are dichotomous in that their components cannot be members of categories $A$ and non-A at the same time (cf. above, the law of the excluded middle). Categories and their relationship towards each other can be depicted as follows:

Fig. 1:

Categories are mutually exclusive.

(For graphic reasons,

B stands for non-A).

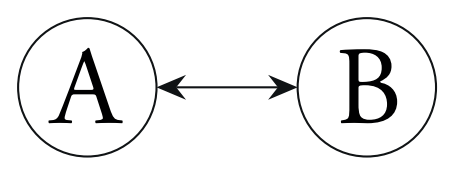

While this picture seems indeed very primitive and simplified, it is basically, what categorytheory is all about: It is a way of simplifying complex structures. Or, as a layperson put it: " [b]y throwing away all the details, an object's structure reveals itself $»^{30}$. In that regard, categories are "general abstract nonsense $»^{31}$.

Category theory has quickly gained prominence and even, at least in the assessment of its proponents, threatens to replace the older set theory as a foundational theory in mathematics ${ }^{32}$.

Fig. 2:

Set theory with union

$A \cup B$.
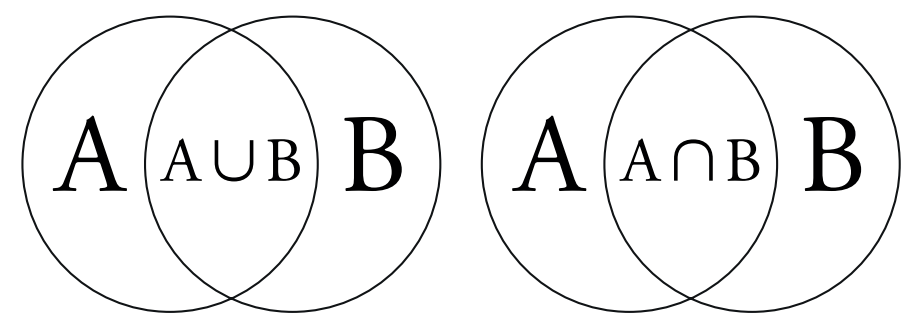

Fig. 3:

Set theory with intersection $A \cap B$.

Sets are defined as opposites but, contrary to categories, they are not mutually exclusive. Thus, some elements can be contained in two (or more) sets, thereby generating an overlap of the sets. This overlap can be defined as union $A \cup B^{33}$. In order to eliminate this overlap, one can posit the intersection $A \cap B$ as a "cut set», that is, it can be "cut out».

Thus, with the uncut overlap, set theory is accounting for the "middle " between two or more sets, while category theory is not. Accordingly, category theory is much more restricted by the classical laws of thought than set theory: the law of bivalence is expressed in the axiomatic nature of the categories (i.e. they are either true axioms or false categories); the law of noncontradiction is expressed in the dichotomous nature of categories (i.e. category $A$ and its members are distinct from category non-A); and the middle is considered as simply not existing

\footnotetext{
28 Jean-Pierre Marquis, "Category Theory», Stanford Encyclopedia of Philosophy [https://plato.stanford.edu/entries/ category-theory/] (accessed 06-27-2017).

29 Rodin, op. cit., p. 252.

30 Robert Seaton in his blog: [http://rs.io/why-category-theory-matters/] (accessed 10-18-2017).

31 Marouis, "Category Theory", art. cit., pp. 221 and 223, based on a quote by Norman Steenrod.

32 At least in the assessment of a proponent of category theory, cf. MARQuIs, "Category Theory", art. cit.. However, this seems very controversial.

33 As used in the example given by Dompere, op. cit., p. 84 and (too) easily transferable to the theological realm as well.
} 


\section{Monika Amsler}

(law of excluded middle). It follows that the great attraction of category formation is that it allows to act according to what is reasonable, "logic", to us. Category formation is classical logic turned into a method.

The "exclusion of the middle" and its somewhat merciless application has generally been an issue in postmodern criticism. Thus, one counterproposal was "fuzzy logic ". Fuzzy logic tries to overcome the rigidity of classical logic and its limitations by inclusion of the middle. It was proposed in 1908 and has gained new attention in more recent scholarship ${ }^{34}$.

The difference between set theory and fuzzy set theory, however, does not affect the algebraic formulae, since $A \cap B$ still describes the intersection between sets $A$ and $B^{35}$. Rather, the changes affect its semantics and philosophical conceptualization. Thus, in fuzzy logic, the dualism of the sets is conceived of as a "duality ${ }^{36}$. The two sets are connected rather than divided and form a continuum instead of an intersection. Fuzzy logic is thereby decidedly post-modern: It criticizes modern logic and points to its deficiencies, while, at the same time, depending on it. Without defined sets, there is no continuum and a continuum generated by defined sets will always allow for deduction, as is expressed in the still valid algebraic formulae.

In the Study of Religion, the notion of a continuum was introduced as early as 1909 to illustrate the relationship between magic and religion, which were, however, seen as phenomena and not as sets ${ }^{37}$. The idea was that magico-religious hybrids could be properly classified by means of a continuum between the sets religion and magic. Yet, in practice, the continuum merely served as a scale: A hybrid was placed on the continuum according to arbitrarily defined criteria and then subsumed under the set to which it seemed more closely related. In the end, the continuum only served to define the extent of a set and to classify the content of the intersection properly in order to get rid of this hybrid middle. In short, the notion of the continuum in the Study of Religion only helped to turn sets into categories.

\section{The Naturalization of Religion as a Category: Part II}

Coming back to the initial question of how religion could become a category without substantial discussion of the matter, a first conclusion may be drawn. It seems now evident that the transition from the notion of religion as an essential and omnipresent phenomenon to an axiomatic and universal category was not a big one. Indeed, the premises remained the same: Religion remains a distinct, universal, and eternal item, standing in a dichotomy to other categories such as magic and science. Similar to the differences between set theory and fuzzy set theory, the difference between the phenomenon religion and the category religion merely affects the semantic level, but not the logical one. If there was a change, it was that the dependency on classical logic and, with that, on the modern paradigm, was increased. Thus, the shift to a category is diametrically opposed to postmodern attempts to macerate modern dichotomies.

\footnotetext{
Cf. Negolta, art. cit., p. 96; Dompere, op. cit.

Cf. DOMPere, op. cit., p. 85.

36 Ibid.

37 In Robert R. Marett, The Threshold of Religion, London, Methuen, 1909; for a discussion, cf. Bernd-Christian Otto, Magie. Rezeptions- und Diskursgeschichtliche Analysen von der Antike bis zur Neuzeit, Berlin - New York, De Gruyter, 2011, pp. 83-87.
} 
Category formation isolates features and regroups them into categories. This separation and isolation of phenomena, structures, signs, and things is inherently characteristic of modern science. The procedure becomes tangible in the form of the modern laboratory, which is all about isolation of mechanisms. The separation of networks into their assumed components, however, does not result in an accurate picture of what is really happening. Rather, the results will always have to be translated into a multifarious system again ${ }^{38}$. To explain light, for example, "[b]oth electromagnetic and quantum theory are needed ${ }^{39}$. The laboratory illustrates very well, how the modern mind functions based on isolation and categorization. Thus, the modern paradigm divides "the whole " up into isolated spheres, the most basic of which are nature, society and the transcendent. Religion, then, comprises a set of further isolated parts of these three spheres and stands against an equal sphere of non-religion.

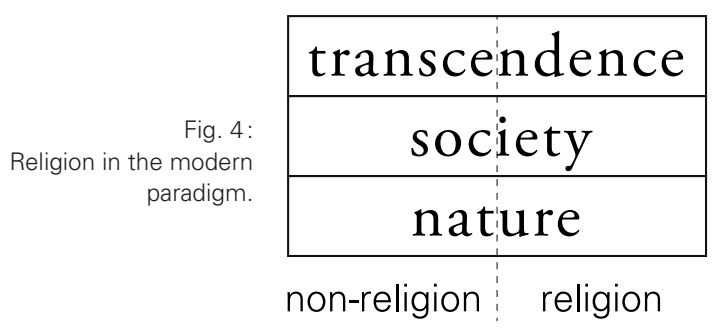

Due to the law of non-contradiction, religion does not have to be defined, but can also be passively deduced from what is perceived as non-religion. This is why religion needs not be defined and still has the meaning of a more or less equally shaped distinct realm in every modern mind.

Again, this is "laboratory work»: while religion may be isolated in this way in the laboratory, the world outside the laboratory confronts the model with other conditions. Whenever scholars try to apply it to data that does not strictly obey to the three laws of thought, they are forced to explain the deficiency of either the data or the model. Out of necessity, the model has then to be combined with other categories. Bruno Latour refers to this procedure as the creation of a hybrid..$^{40}$ The following random example illustrates the insufficiency of such an isolated and encapsulated sphere of religion:

Pervasive and invasive, religious mentality shaped the lens through which the people of the Roman world viewed their surroundings and everyday routines. Religious vocabulary and imagery seeped into every strata of language and helped people mediate, explain, and interpret their interactions with their environment. Names and characteristics of gods, the messages of myths and legends, and the force of folk beliefs underlay ancient understanding of both natural phenomena and human situations just as scientific "truth" outlines the contours of our world today. Religion, or to be more precise, what we today call religion, encompassed all. ${ }^{41}$

38 Cf. also Bruno Latour's description of what he calls the "work of translation " (op. cit., pp. 10-13).

39 NegoltA, art. cit., p. 97.

40 Cf. Latour, op. cit., pp. 1-12.

41 Yaron Z. Eliav, "A Scary Place: Jewish Magic in the Roman Bathhouse ", in Leah Di Segni, Yizhar HiRschfeld, Joseph Patrich, Rina Talgam eds., Man Near a Roman Arch. Studies Presented to Prof. Y. Tsafrir, Jerusalem, The Israel Exploration Society, 2009, pp. 88-97, here p. 88. 


\section{Monika Amsler}

The model of a distinct sphere of religion can easily be mistaken with a category, since they are both generated on the basis of the same logical premises. The insufficiency of such a static category of religion is then also expressed through the many prefixed modifications that proliferate in the field and do not contribute to a clear taxonomy of the category. Some qualifications exhibit an unclear notion of a category (i.e. "taxonomic category») ${ }^{42}$, or are pleonasms (i.e. "comparative crosscultural category " $)^{43}$. It seems that the category is increasingly conflated with a term, since only terms are used " (o)ften with [a] modifying word or phrase, as abstract term, general term, term of abuse, term of endearment ${ }^{44}$, but not categories or concepts. Moreover, many modifications exhibit a binary structure such as: "folk category " vs. "academic category " ${ }^{45}$ as equal to " firstorder" vs. "second-order category"; " historical category" vs. "essential, ahistoric category"; " insider/emic category" vs. "outsider/etic category"; the "local category" vs. "universalized category ${ }^{46}$. Such binary modifications have also been applied to discourses: "polemical and affirmative discourses", "discourses of exclusion and inclusion", "contemporary mainstream and elitist discourses ${ }^{47}$. Indeed, especially in historical discourse analysis, the way in which a discourse differs from a category is often not evident, especially in cases where the "spatiotemporal specificity " of terms is neglected ${ }^{48}$. Thus, obviously, religio and mageia cannot refer to religion and magic, and yet, still, the conflation is omnipresent ${ }^{49}$.

Then there are modifications that aim at un-categorizing categories by macerating their boarders, thereby turning them into fuzzy sets. Such is the nature of the "open-ended category $\|^{50}$, " unbounded category $\|^{51}$, " polythetic category ${ }^{52}$, "ambiguous " or " multi-layered category $\|^{53}$ and the "graded category $\|^{54}$.

While binary categories generate even more dichotomies, fuzzy ones try to reduce the number and importance of dichotomies. They create a category of religion that is capable of including hybrids instead of creating them. Thus, instead of creating hybrids via a rigid selection by means of sufficient criteria for admission to the category, the criteria are held more flexible. Since the category of religion that was conceptualized according to classical logic has proven to be unpractical in many ways, it seems only conclusive to turn to fuzzy categories for a solution.

\footnotetext{
42 Russell T. Mccutcheon, Manufacturing Religion. The Discourse on Sui Generis Religion and the Politics of Nostalgia, New York - Oxford, Oxford University Press, 1997, esp. 127-157, here pp. 152 and 156.

43 Mccutcheon, op. cit., p. 149.

44 Cf. [http://www.oed.com/view/Entry/199409?rskey=gWgTLN\&result=1\&isAdvanced=false\#eid] (accessed 11-08-2017).

45 Variably also called analytical, scholarly or intellectual category.

46 All the examples are taken from MCCUTCHEON, op. cit., pp. 127-157.

47 Отто, art. cit., pp. 29, 46, 47.

48 Cf. Tim Murphy, "Wesen und Erscheinung in the History of the Study of Religion: A Post-Structuralist Perspective", Method \& Theory in the Study of Religion 6.2 (1994), pp. 119-146, here p. 120, citing Hubert Seiwert referring to the misguided assumption that Buddhism in China in the eighth century and Buddhism in Ceylon in the twentieth century refer to the same thing, or, as might be reformulated for the present purpose, to the same discourse.

49 Cf. for example, Kimberly B. Stratton, "Magic Discourse in the Ancient World», in Bernd-Christian Otto, Michael Stausberg eds., Defining Magic. A Reader, Sheffield, Routledge, 2013, pp. 243-254.

50 Cf. Mccutcheon, op. cit., p. 131.

51 Cf. Benson Saler, Conceptualizing Religion: Immanent Anthropologists, Transcendent Natives and Unbounded Categories, New York - Oxford, Berghahn, 2000 (1993), pp. 253-264.

52 Cf. Отто, art. cit., p. 39

53 Cf. Ibid., p. 51.

54 Cf. Saler, op. cit., p. xii.
} 


\title{
Religion: A Fuzzy Category?
}

\author{
The Polythetic Classification
}

A polythetic classification aims at a taxonomy by means of classes "which surrendered the idea of perfect, unique, single differentia - a taxonomy that retained the notion of necessary but abandoned the notion of sufficient criteria for admission to a class $"^{55}$. The background of polythetic classification is botany, where between fifty to one hundred characteristics are used to define a class (or taxon) "the possession of any one of which is sufficient for admission to the taxon $n^{56}$. The goal of such numerical taxonomies is for the taxa (or classes) to embrace new species. The taxa that were once established based on a monothetic classification, however, remain unchanged. Thus, "[n]o useful new zoological or botanical taxonomies of any great size will be produced by the computers, at least until taxonomists are ready to abandon the classifications of the past in toto ${ }^{57}$.

The same is true for Jonathan Z. Smith's attempt to devise a "polythetic classification of early Judaism ${ }^{58}$. He instantly turned to texts that had previously been defined as Jewish (i.e. the Hebrew Bible, Philo, Paul and Josephus) and so called Jewish symbols to define and verify the criteria ${ }^{59}$. Thus, insofar as Smith did not depart from the taxon "Judaism/Jewish " he could not obtain a polythetic classification that differed from a former monothetic one. Such a procedure is conflicting in that it aims at macerating the boarders of the category (or taxon), while at the same time maintaining them.

\section{Family Resemblance}

A way to reduce the complexities of numerical classification is to exchange the therefore indispensable high number of characteristics with the notion of Wittgenstein's "family resemblance". Benson Saler proposed this approach to describe a category of religion. He suggests that a prototype should be chosen to which the other members of the family are assigned by resemblance. However, since Saler is not interested in creating a new category, but to account for an already existing one, the choice of a prototype is arbitrary on the grounds that one member seems to be " a more plausible representative of a certain category than another "60. For example, if it were assumed that the members of the family religion were religions, this would imply that " [s]ome religions, in a manner of speaking, are "more religious" than others "61, namely those who come closer to the prototype. According to Saler, the appointment of a prototype leads to a hierarchization within the category, turning it into a "graded category" 62 . In fact, the prototype is nothing else than the tertium comparations and responsible for the

\footnotetext{
55 SмITH, art. cit., p. 4.

56 Ibid., p. 8.

57 Richard E. Blackwelder, "A Critique of Numerical Taxonomy", Systematic Zoology 16.1 (1967), pp. 64-72, here p. 71.

58 SMITH, art. cit., p. 9.

59 However, SMITH, art. cit., p. 138, n. 35-37, referred to all of the three collections that he used as being Jewish.

60 SALER, op. cit., p. xiv. Interestingly, Saler anticipates the category already in this statement. If "family resemblance" is not used to define a category but to include other "signs and things " in a pre-defined category, then there is really no difference between a polythetic classification and a classification by means of "family resemblance ".

61 Ibid., p. xiv.

62 Ibid.
} 
different kinds of -centricisms of comparisons (here expressed in the hierarchy). While this sketch certainly accounts for the problems that are generally encountered when using religion as a category, it is not clear, what analytical purpose such a " graded category" could serve. After all, a category should serve as an auxiliary for research and not vice versa.

Polythetic classification and graded categories were both introduced to allow for permeability between categories. While the theory seems to be sound, foregoing two of the three classical laws of thought (no excluded middle; $A$ can be non-A at the same time), the practice failed because the category was not established from scratch but based on a pre-theoretical notion of a category.

\section{Homeostasis}

Closely related to the polythetic mode of definition is the homeostatic property cluster. It differs from the former in that the content of the category is visualized as properties that are nonaccidentally related. Mark Gardiner and Michael Stausberg introduce this type of definition in the Oxford Handbook of the Study of Religion. They describe the content of the category as a " cluster of commonly mentioned features, e.g. actions, attitudes, behaviors, beliefs, communities, discourses $[\ldots] \|^{63}$. The cluster "can be hierarchically ordered, in the sense that the presence of some might provide greater weight than others for applying the definiendum ${ }^{64}$. The authors suggest critically that the decision over the number of necessary criteria for an admission to the category is in any case arbitrary. They also recognize the problem of the naturalization of a given term: if religion is defined homeostatically, the definition will be based on the use of the word and common-sense assumptions. Common-sense, however, will always relegate religion into the isolated spot discussed above.

\section{Placing the Excluded Middle into a New Category}

Another case that might be mentioned here is the one in which a formerly excluded middle is turned into a category in its own right. This might look like a rehabilitation of previously marginalized data but is, by force of the newly generated dichotomies (i.e. excluded middles), just a postponement of the problem.
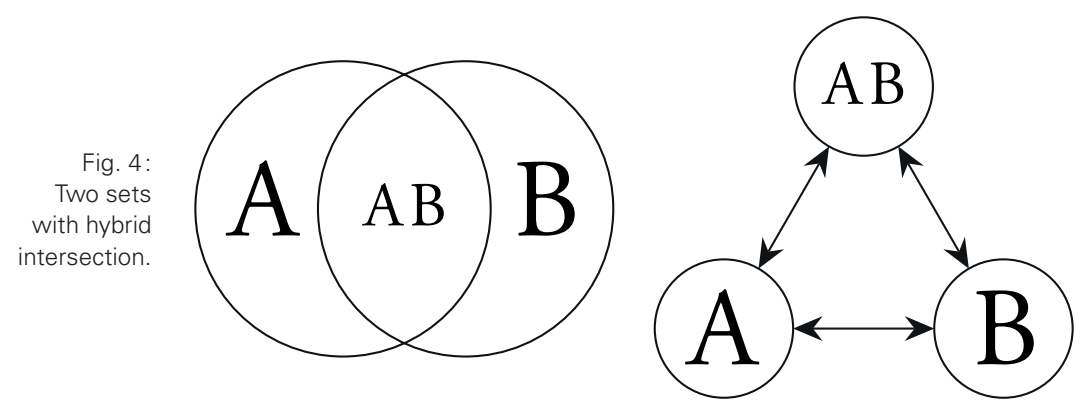

Fig. 5:

Hybrid

intersection

is turned into

a distinct

category.

63 Gardiner, Stausberg, art. cit., p. 21.

64 Ibid. 
Magic is such a category of hybrids. Other such categories are, for example, "heresy" or "therapy ». The creation of hybrid categories attacks and reconfirms modern logic at the same time: the exclusion of the middle is criticized, but the importance of categories is confirmed. Such is the perpetuum mobile of postmodern scholarship.

Even though categories of hybrids seem to bear the potential of provocative, subversive and paradoxical conclusions, their trivia lies in that they can only subvert long held prejudices against their respective content.

\section{The Fallacies of Classical Logic}

Categorization is deeply entwined with the Modern Academy: it is considered the backbone of academic reason and even part of human nature:

Issues related to concepts and categorization are nearly ubiquitous in psychology because of people's natural tendency to perceive a thing as something. We have a powerful impulse to interpret our world. This act of interpretation, an act of "seeing something as $\mathrm{X}$ " rather than simply seeing it (Wittgenstein, 1953), is fundamentally an act of categorization " (emphasis in original). ${ }^{65}$

Yet, there is a significant difference between the organization of tangible and visible things into categories such as "colours", "furniture" or "trees" and abstract ideas as gathered in "religion", "the holy" or "philosophy". It is what Isaiah Berlin called the "Ionian fallacy of asking what everything is made of ${ }^{66}$. However,

[T]he Ionian philosophers themselves may be wholly guiltless of this, since what they were probably asking were questions of physics, from which metaphysical ones were perhaps not clearly distinguished in their day. But the form which this inquiry has taken in later times, from Aristotle to Russell, is a search for the ultimate constituents of the world in some nonempirical sense. ${ }^{67}$

Thus, the form which Aristotle's reflections on metaphysics have taken in the course of the history of their exegesis is a category mistake: Aristotle's logic concerns a reality, a paradigm, that is not divided according to modern standards. Many of his statements had a much more tangible basis than the ideas to which they have come to be applied.

Appropriate fragmentation, classification, and synthesis constitute the body of scientific work. Simply put: every method aims at facilitating fragmentation and every theory aims at contributing to the reliability of the synthesis. Yet, there have been and there still are other ways of generating knowledge (or, in more mercantilist terms: knowledge production). They just sank into oblivion. Classical logic, which fragmentation and categorization are based on, has reached

\footnotetext{
65 Robert L. Goldstone, Alan Kersten, "Concepts and Categorization», in Alice F. Healy, Robert W. Proctor eds., Handbook of Psychology. Vol. 4: Experimental Psychology, New York, Wiley, 2003, pp. 599-622, here p. 607.

66 Berlin, art. cit., p. 76.

67 Ibid.
} 


\section{Monika Amsler}

its epistemological limits in many ways. The academic repertoire needs to be enhanced with other "logics", which can handle the fact that a proposition might be neither true nor false and that $A$ can be non-A at the same time without qualifying such data as a priori non-scientific.

This is not to say that classical logic should be discarded but that its use should be a choice and not done unwittingly, by force majeure. Similarly, if the conceptualization of religion as a category proves useful in certain cases, then there seems to be no reason why it should not be used as such. The application of the method "category formation " should, however, be a conscious and grounded decision.

\section{Consolidation: The Missing Concept of «Transcendence Without a Contrary»}

French philosopher Bruno Latour has made the point that despite the deficiencies of the Modern project «we do not wish to become premoderns all over again " ${ }^{68}$. This is certainly true. At the same time, the classical (categorizing) paradigm has done all that it could for the academy ${ }^{69}$. What is required to proceed further in academic epistemology is, however, not postmodern logics, such as fuzzy logic discussed above, since they are dependent on classical logic. Rather, a logic is needed that differs fundamentally from classical logic in order to provide a choice between different systems of argumentation. This is tricky in that it is very difficult for scholars trained in classical logic to find anything but this very logic reasonable at all. In order to find another logic or, possibly, other logics, the inconceivable needs to be conceived of or, at least, the very possibility of its existence needs to be accepted.

As was discussed above, scholars of religion have come across many problems that intrigue other disciplines as well, among them also the so-called exact sciences. Scholars of religion are constantly confronted with the limits of classical logic in explaining their object of study, which never seems to agree with the data in its rigidity as a category or becomes seemingly insignificant as soon as the borders of the category are softened. The Study of Religion has, from its very beginnings onwards, been an exercise in the application of apparently ready-made categories, their highly difficult justification, complex alterations and negotiations. Thus, the contribution of the Study of Religion should not be underestimated in the development of new paradigms - not least because the subject of study is mostly paradigms that differ from the academic one $^{70}$. Therefore, the contribution of scholars of religion to the pan-academic endeavor of finding different "logics» is necessary, if not crucial.

A first step in this direction is acknowledging that categorization is a method for analysis stricto sensu. Other than categories, concepts are flexible; they change or disappear and do not naturally have exact opposites. It appears that in recent studies, religion has been called

\footnotetext{
68 LATOUR, op. cit., p. 140.

69 Thus, for example, Dompere, op. cit., p. XXVII, writes in favor of fuzzy logic: "The fuzzy paradigm ensures the practice of the principle of methodological doubt, activates the intellect and liberates cognitive agents from the slavery of mental habits without innovation".

70 Cf. on this issue Annette Y. Reed, "Categorization, Collection, and the Construction of Continuity: 1 Enoch and 3 Enoch in and beyond "Apocalypticism" and "Mysticism" ", Method \& Theory in the Study of Religion 29.3 (2017), pp. 268311, esp. pp. 301-302.
} 
alternately a concept as well as a category ${ }^{71}$. Indeed, a category of religion is a distinct concept. But against the dominant dogmatic-axiomatic nature of categories it has to be held that religion can be conceptualized in different ways as well - preferably time- and space-bound in order to avoid the pitfall of the eternal universal.

For the historical Study of Religion, on the other hand, as well as for the study of episteme building on other than the modern dichotomies, the concept of a "transcendence without a contrary" is needed ${ }^{72}$. However, since the concept is not natural to us, there is no more appropriate term for it. Exactly because of that, such a concept bears the possibility of being described, maybe renamed, for scholarly purposes. So far, the concept is part of Bruno Latour's "symmetrical anthropology " and is characterized by a non-qualifying attitude to what is perceived by the scholar as truth or error; the simultaneous study of "the production of humans and nonhumans " $^{73}$; and the abstention from an a priori "othering". In other words, the concept is independent from constraints by the three classical laws of thought (bivalence, non-contradiction and exclusion of the middle). Research done on such a symmetric basis will not only generate a more objective picture of conditions, but also yield new insights into fundamentally different ways of reasoning - beyond categorization.

\author{
Monika Amsler \\ Universität Zürich \\ Religionswissenschaftliches Seminar \\ Kantonsschulstrasse 1 \\ $\mathrm{CH}-8001$ Zürich \\ monika.amsler@uzh.ch
}

\footnotetext{
71 Cf. as examples Jonathan Z. SMith, "Religion, Religious, Religions", in Mark C. Taylor ed., Critical Terms for Religious Studies, Chicago, University of Chicago Press, 1998, pp. 269-284, here p. 269, where he refers to religion as a "second-order generic category" and ibid. p. 281, where religion becomes a "second-order generic concept"; HANEGRAAFF, art. cit., p. 577 ("concept») and p. 586 ("category»); NongBRI, op. cit., generally refers to religion as a concept, but casually also as category, for example on pp. 65 and 159.

72 Borrowed from Latour, op. cit., p. 135.

73 Ibid., p. 103.
} 